\title{
7. CORRELATION OF MAGNETOSTRATIGRAPHY AND NANNOFOSSIL BIOSTRATIGRAPHY IN UPPER CRETACEOUS AND LOWER PALEOCENE SEDIMENTS OF THE WALVIS RIDGE AREA ${ }^{1}$
}

\author{
Hèlène Manivit, Laboratoire Associé C.N.R.S. No. 319 and Laboratoire de Biostratigraphie B.R.G.M., B.P. 6009, \\ 45018 Orléans, Cedex, France \\ and \\ Hugues Feinberg, Laboratoire de Micropaléontologie, Université de Paris VI, 75230 Paris, Cedex, France
}

\begin{abstract}
A detailed biostratigraphic and magnetostratigraphic correlation is established at four sites and provides better resolution for the chronology of the lower Paleocene and the Maestrichtian near the Cretaceous/Tertiary boundary. A good correlation with the Gubbio Section, Italy, is established.
\end{abstract}

\section{INTRODUCTION}

After the first paper by Bramlette and Martini (1964) on the great change in calcareous nannofossils between the Maestrichtian and Danian, many detailed taxonomic and stratigraphic studies of sections across the Cretaceous/Tertiary boundary from various parts of the world have been published. Such works include studies from New Zealand (Edwards, 1966), southwestern France (Hay and Mohler, 1967), Denmark (Perch-Nielsen, 1969), and Alabama (Worsley, 1974). From northern Spain (Percival and Fisher, 1977) and from southern Spain (Romein, 1977) abundance data of dominant species were interpreted to support a temperature decrease in the late Maestrichtian that led to increased latitudinal provincialism.

After a detailed biostratigraphic study of circum-Tethyan and Danish outcrops with Cretaceous/Tertiary boundary sections, Romein (1979) presented evolutionary lineages of early Paleogene taxa. In 1981, K. PerchNielsen gave a detailed biostratigraphic documentation of the El Kef Section (Tunisia) using the scanning microscope (SEM); she also demonstrated a progressive phylogeny of Cretaceous survivors and of the new genera evolved from the surviving Cretaceous stock. Thierstein and Okada (1979), using quantitative taxonomic analyses, provided detailed evolutionary documentation of late Campanian to early Danian nannofossil assemblages from a well-preserved deep sea section in the North Atlantic. Thierstein (1981) documented the global biogeography of the calcareous communities and their evolutionary changes across the Cretaceous/Tertiary boundary in an extensive sample set. The sedimentological and paleontological data from Site 356 suggest that carbonate fixation by phytoplankton decreased dramatically at the Cretaceous/Tertiary boundary. From a detailed stratigraphic and chronologic comparison with the Gubbio reference section studied by Alvarez et al.

\footnotetext{
${ }^{1}$ Moore, T. C., Jr., Rabinowitz, P. D., et al., Init. Repts. DSDP, 74: Washington (U.S. Govt. Printing Office).
}

(1977), Thierstein concluded that calcareous phytoplankton extinctions were globally synchronous.

Other studies of the terminal Cretaceous mass extinctions were largely concerned with the possibility of extraterrestrial body impacts suggested by Alvarez et al. (1980) on the basis of geochemical evidence. In well over 15 sections exposed on land and recovered in DSDP holes across the globe, high iridium contents are documented at the Cretaceous/Tertiary boundary. A somewhat more detailed extinction scenario was proposed by Hsü et al. (1982), using the record at DSDP Site 524, drilled on the Walvis Ridge near the Leg 74 sites. It is difficult to affirm at present if the geochemical changes observed are the effects or the causes of mass mortality. Collection of detailed data and the development of a chemo-stratigraphic section will enable us to determine the synchronism or diachronism of the various events taking place at this boundary. The relatively complete sections recovered during Leg 74 hold especial promise for shedding additional light on these issues and appear particularly worthy of detailed study.

\section{MAGNETOSTRATIGRAPHY}

Holes $525 \mathrm{~A}$ to 529 provide a stable magnetic record and a full sequence of the calcareous nannofossil zones. A detailed magnetostratigraphic analysis of the sedimentary sequences by Chave (this volume) allows us to compare the magnetochronology with the full sequence of calcareous nannofossil events recognizable in Leg 74 cores and also with other sequences of the same time interval. Figure 1 gives the polarity sequence in the two most complete holes, 525A and 527, and correlates it with the standard sequence of marine magnetic anomalies (Ness et al., 1980; Alvarez et al., 1977). The proposed correlation is supported by the calcareous nannofossil events and is consistent with the magnetostratigraphy of Gubbio, Italy. We use the magnetostratigraphic terminology of Tauxe et al. (in press), where magnetic chrons are associated to the corresponding magnetic anomaly numbers and may be divided into subchrons by the ad- 


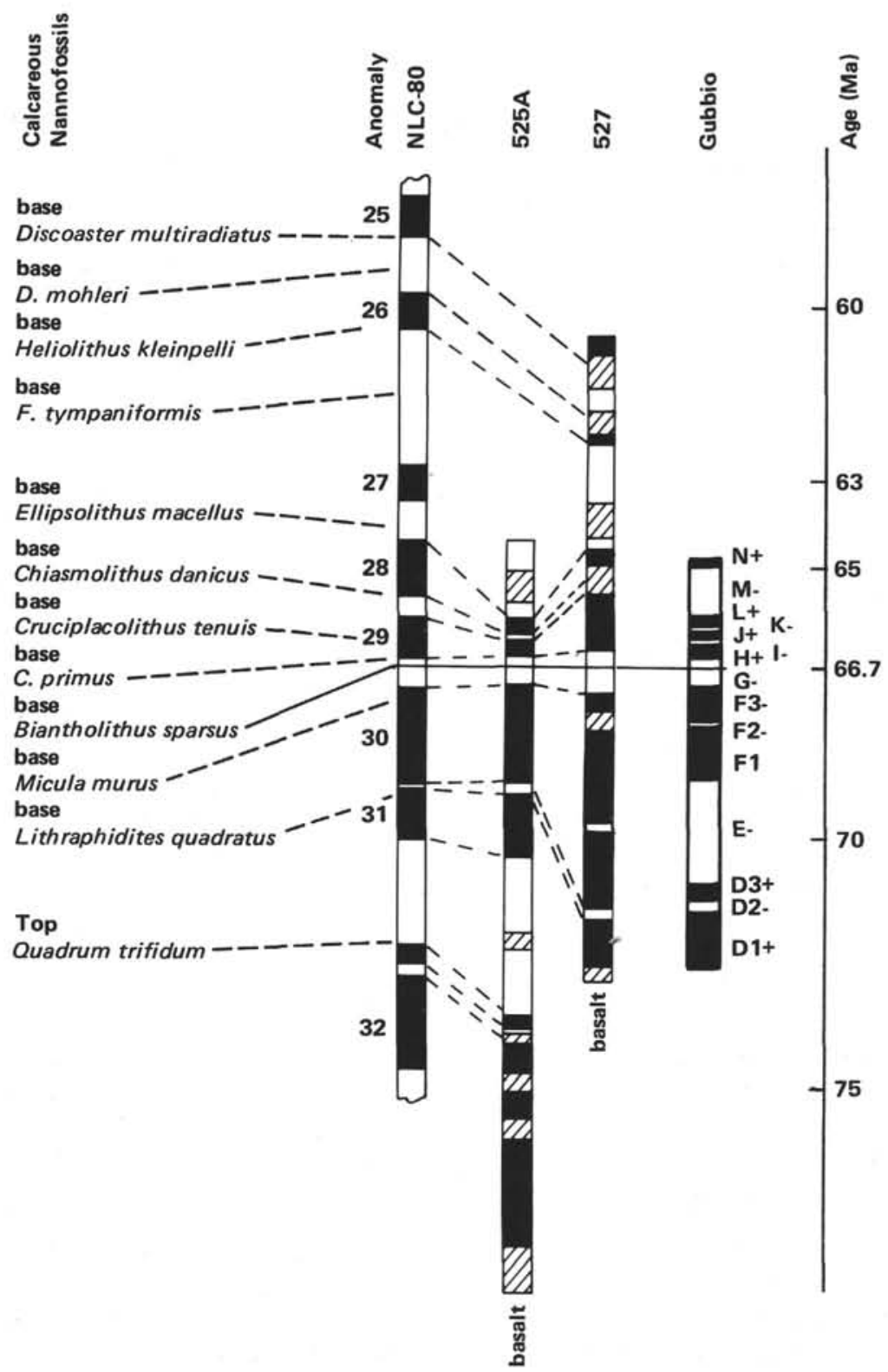

Figure 1. Correlation of magnetostratigraphy and biostratigraphy from Holes 525A527. The $66.7 \mathrm{Ma}$ level is identified as the Cretaceous/Tertiary boundary.

dition of $\mathrm{N}$ or $\mathrm{R}$, which refers to the normal or reversed segment of the chron.

In Hole 525A the Cretaceous/Tertiary boundary was recognized at $451.715 \mathrm{~m}$ sub-bottom, in Sample 525A40-11, $11.5 \mathrm{~cm}$, within Magnetic Subchron C29R. This boundary in both Holes 525A and 527 is correlated with the polarity epoch $\mathrm{G}$ - in the Gubbio section (Alvarez et al., 1977). Following Chave (this volume), we utilize the geochronologic data of Ness and others (1980), which is based on a recalibration of LaBrecque and others' (1977) magnetic and absolute-age timescale. Extrapolations from regional magnetic anomaly maps indicate that Hole 525A was drilled on Anomaly $32 \mathrm{~N}$, Hole 527 on Anomaly $31 \mathrm{~N}$, and Hole 528 on Anomaly 31R. These extrapolations are consistent with the biostratigraphic ages of the oldest sediments recovered and with the hypothesis that the Walvis Ridge formed by seafloor-spreading processes.
The correlation of nannoplankton events recognized in Holes 525A and 527 and the magnetic chrons identified are shown in Figures 2 and 3. For the Danian interval these correlations agree with those found by Okada and Thierstein (1979). The lowermost occurrence of $\mathrm{Mi}$ cula murus correlates in our sites with Magnetic Chron $30 \mathrm{~N}$, the lowermost occurrence of Lithraphidites quadratus with Magnetic Chron $31 \mathrm{~N}$ and the highest occurrence of Quadrum trifidum with Magnetic Chron 32N.

\section{BIOSTRATIGRAPHY}

The Cretaceous/Tertiary boundary is present in four continuous sedimentary sequences and is bracketed by diverse and typical nannofossil biotas. All sediments are calcareous oozes with moderately well preserved foraminifers. In the basal Paleocene, the input of volcanic materials has altered the lithology of the sediments, yet 


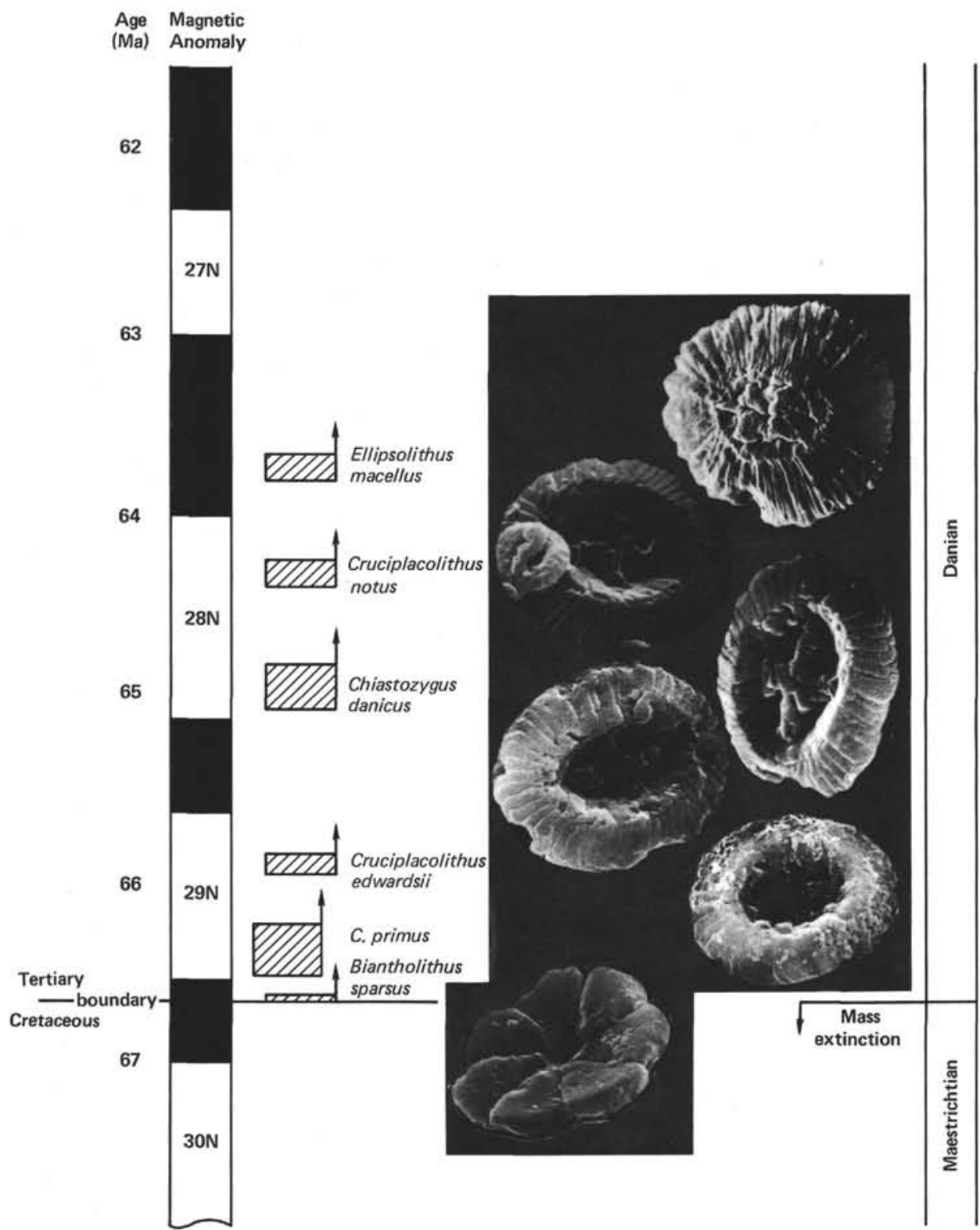

Figure 2. Correlation of lower Paleocene nannoplankton events and magnetic anomalies in Holes 525A and 527.

the basal Tertiary Globigerina eugubina Zone was consistently recovered.

Detailed investigations of the nannofossils with SEM and light microscope allows us to place the Cretaceous/ Tertiary boundary at $451.715 \mathrm{~m}$ sub-bottom depth in Hole $525 \mathrm{~A}$ and at $280.02 \mathrm{~m}$ sub-bottom depth in Hole 527 , on the basis of the first occurrence of the Tertiary nannofossils Markalius astroporus, $M$. reinhardtii, Biantholithus sparsus, Placozygus sigmoides, and Thoracosphaera species.

As at other DSDP sites, a "transitional interval" of about $2 \mathrm{~m}$ is found above the Cretaceous/Tertiary boundary, where nannofossils occur that have been considered exclusively Cretaceous species. In this interval the abundant to common Cretaceous nannofossils are either the remains of the last survivors, soon to become extinct, or they represent Cretacous forms reworked from older sediments. In Hole 525A, samples directly above the Cretaceous/Tertiary boundary consist of over $90 \%$ characteristically Cretaceous taxa. This content decreases to less than $20 \%$, at $1.70 \mathrm{~m}$ above the boundary. The most common Upper Cretaceous coccoliths are robust species such as Micula staurophora, Arkhangelskiella cymbiformis, Eiffellithus turriseiffeli, and Watznaueria barnesae. Some less dissolution resistant species, such as Prediscosphaera cretacea are common; some, such as $M$. prinsii, are rare.

Thoracosphaera and Braarudosphaera species are the first nannofossils to appear after the catastrophic mass mortality. Thoracosphaera occur in upper Cretaceous samples in low abundance, but become common in basal Tertiary assemblages of Holes 525A and 527. Braaru- 


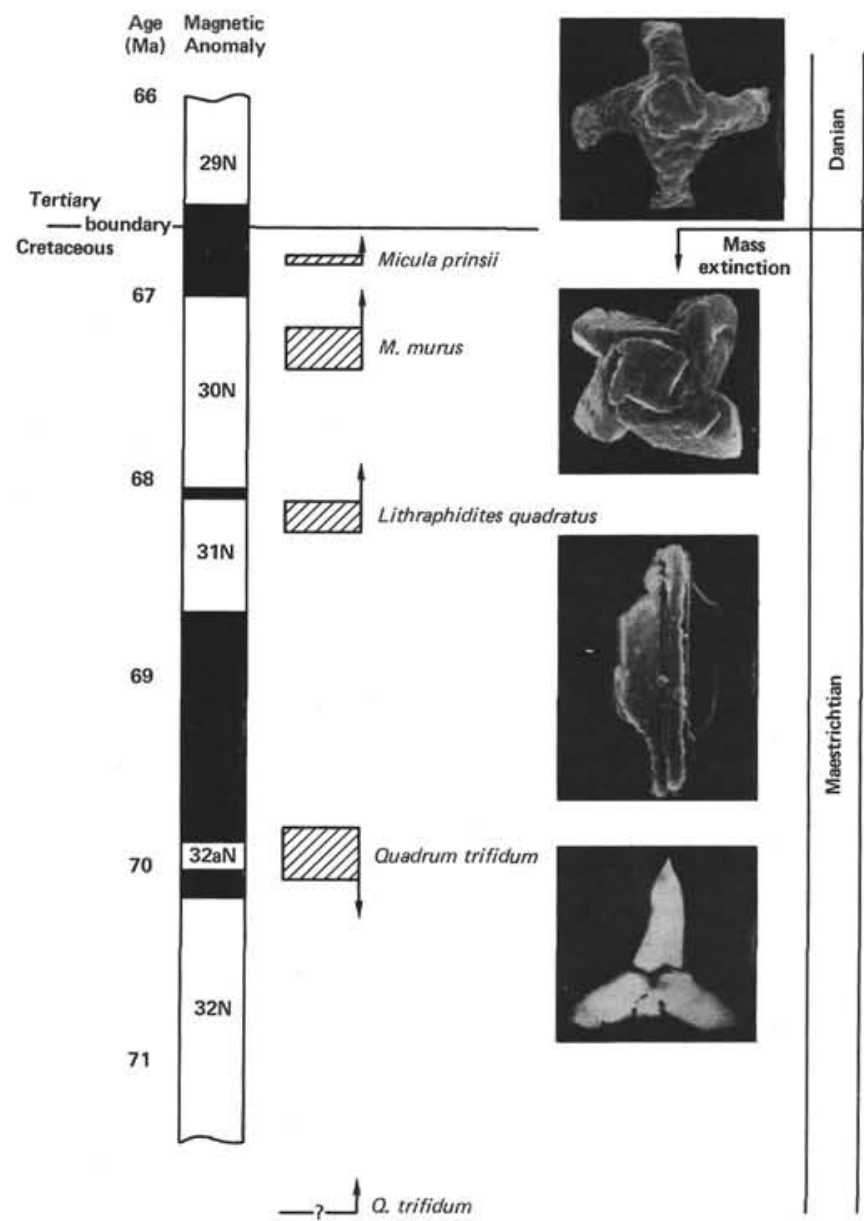

Figure 3. Correlation of Maestrichtian nannoplankton events and magnetic anomalies in Holes 525A and 527.

dosphaera cf. bigelowi is rare in the basal Danian of Leg 74 sites.

No structural or preservational differences have been observed in SEM studies of assemblages below and above the Cretaceous/Tertiary boundary. The only difference lies in the increase in abundance of Thoracosphaera, Cyclagelosphaera reinhardtii, Markalius inversus, Neocrepidolithus, and Placozygus sigmoides.

It seems possible that Cretaceous nannofossils survived the Cretaceous/Tertiary boundary for a short time and that the observed Cretaceous taxa are not reworked.

\section{BIOZONATION}

Table 1 gives a tentative correlation with Martini's zonation (1971) and that of Romein (1979) and also with the succession of events observed at Sites 525-529. They are compared to those proposed by Perch-Nielsen (1981b) for the El Kef section in Tunisia, which may be the most complete and well-preserved section across the Cretaceous/Tertiary boundary.

At Leg 74 sites just above the Cretaceous/Tertiary boundary, the very small Biscutum? romeini and B. parvulum are not found; these nannofossils are only distinguishable in the SEM and appear to be restricted to low latitudes, like Toweius petalosus, which is present in Tunisia and Spain but absent in Leg 74 samples.

In Holes 525 and 529 the first small Cruciplacolithus primus (about $3 \mu \mathrm{m}$ ) occurs less than 1.5 to $2 \mathrm{~m}$ above the Cretaceous/Tertiary boundary in an interval where Placozygus sigmoides increases rapidly in size (about $7 \mu \mathrm{m}$ at this level).

In lower Paleocene sediments of Leg 74 sites, the first appearances of $C$. edwardsii, Chiasmolithus danicus, and subsequent nannofossil events occur in the same sequence as described by Perch-Nielsen (1981b) and Romein (1979). Lower Paleocene nannofossil assemblages from the Walvis Ridge show a lower diversity than those in Tunisia: fewer Braarudosphaera are present and the holococcoliths and small Biscutum are generally absent. This phenomenon may be due to bioprovincialism or to dissolution.

Biantholithus sparsus are present at the base in all Danian intervals of Leg 74 sites. Thoracosphaera sp., very rare in the Maestrichtian, occurs commonly just above the Cretaceous/Tertiary boundary.

The Danian assemblages from the Walvis Ridge area are characterized by various species of Markalius, $C y$ clagelosphaera, Placozygus, Neochiastozygus, Biantho- 
Table 1. Comparison between the different zonations of Martini (1971), Romein (1979), the events given by Perch-Nielsen (1981b), and those used in the four sites of Leg 74 in the Maestrichtian and Danian intervals.

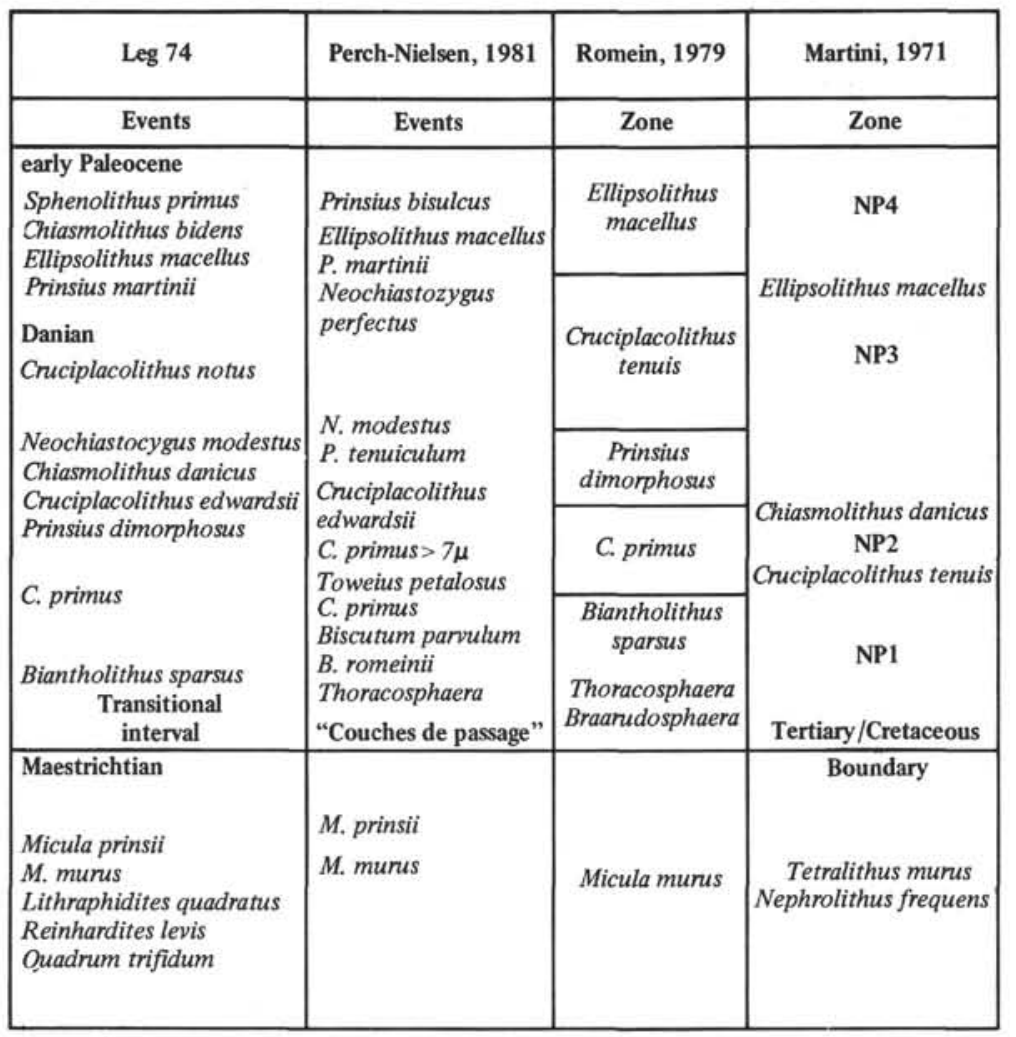

lithus, and Cruciplacolithus, and appear to resemble more closely those from Denmark than those from Tethyan areas.

In the upper Maestrichtian, typical Micula prinsii are present at Sites 525-527 and 528, and are limited to the uppermost $1 \mathrm{~m}$ before the boundary, where they occur with few coccoliths and rare Thoracosphaera species.

Prediscosphaera grandis, P. majungae, and Cribrosphaerella daniae are present in the highest samples of upper Maestrichtian sediments.

The detailed nannoplankton biostratigraphy of the complete sequences of the Cretaceous and lower Paleocene in these sites from the Walvis Ridge has provided an assemblage of mid-latitude nannofossils comparable to those in the Danian of Denmark and also provides a magnetostratigraphic record comparable to the Gubbio section of Italy.

\section{REFERENCES}

Alvarez, L. W., Alvarez, W., Asaro, F. and Michel, H. V., 1980. Extraterrestrial cause for the Cretaceous-Tertiary extinction. Science, 208(no.4448).

Alvarez W., Arthur, M. A., Fischer, A. G., Lowrie, W., Napoleone, G., Premoli-Silva I., and Roggenthen, W. M., 1977. Upper Cretaceous-Paleocene magnetic stratigraphy at Gubbio, Italy. V. Type section for the Late Cretaceous-Paleocene geomagnetic reversal time scale. Geol. Soc. Am. Bull., 88:367-389.

Bramlette, M. N., and Martini, E., 1964. The great change in calcareous nannoplankton fossils between Maastrichtian and Danian. Micropaleontology, 10:291-322.
Edwards, A. R., 1966. Calcareous nannoplankton from the uppermost Cretaceous and the lowermost Tertiary of the mid Waipara section, South Island, New Zealand. N. Z. J. Geol. Geophys., 9: 481-490.

Hay, W. W., and Mohler, H. P., 1967. Calcareous nannoplankton from early Tertiary rocks at Pont-Labau, France, and Paleoceneearly Eocene correlations. J. Paleontol., 41:1505-1541.

Hsü, K. J., Hé, Q., McKenzie, J. A., Perch-Nielsen, K., LaBrecque, J., et al., 1982. Mass mortality and its environmental and evolutionary consequences. Science, 216(no. 4543):249-256.

LaBrecque, J. L., Kent, D. and Cande, S. C., 1977. Revised magnetic polarity time scale for Late Cretaceous and Cenozoic time. Geology, 5:330-335.

Martini, E., 1971. Standard Tertiary and Quaternary calcareous nannoplankton zonation. In Farinacci A. (Ed.), Proc. II Planktonic Conf., Roma, 1970 (Vol. 2): Rome (Edizioni Tecnoscienza), 739-785.

Ness, G., Levi, S., and Couch, R., 1980. Marine magnetic anomaly timescales for the Cenozoic and late Cretaceous: A precis, critique, and synthesis. Rev. Geophys., 18:753-770.

Perch-Nielsen, K., 1969. Die Coccolithen einiger dänischer Maastrichtien und Danienlokalitaten. Meddel. Dansk. Geol. For., 19: $51-68$

1981a. Les coccolithes du Paleocene près de El Kef, Tunisie et leurs ancetres. Cah. Micropaleont., 1:7-23.

1981b. New Maastrichtian and Paléocene calcareous nannofossils from Africa, Denmark, the USA and the Atlantic, and some Paleocene lineages. Eclogae Geol. Helv., 74(3):831-863.

Percival, S. F., and Fischer, A. G., 1977. Changes in calcareous nannoplankton in the Cretaceous-Tertiary biotic crisis at Zumaya, Spain. Evol. Theory, 2:1-35.

Romein, A. J. T., 1979. Lineages in early Paleogene calcareous nannoplankton. Utrecht Micropaleontol. Bull., 22:1-78.

Tauxe, L., Tucker, P., Peterson, N. P., and LaBrecque, J. L., in press. Magnetostratigraphy of Leg 73 sdiments. In Hsü, K. J., 
H. MANIVIT, H. FEINBERG

LaBrecque, J. L., et al., Init. Repts. DSDP, 73: Washington (U.S. Govt. Printing Office).

Thierstein, H. R., 1981. Late Cretaceous nannoplankton and the change at the Cretaceous-Tertiary boundary. In Warme, T. E., Douglas, R. C., and Winterer, E. L., (Eds.), The Deep Sea Drilling Project: A Decade of Progress. Soc. Econ. Paleont. Mineral. Spec. Publ., 32:355-394.
Thierstein, H. R., and Okada, H., 1979. The Cretaceous/Tertiary boundary event in the North Atlantic. In Tucholke, B. E., Vogt, P. R., et al., Init. Repts. DSDP, 43: Washington (U.S. Govt. Printing Office), 601-616.

Worsley, T., 1974. The Cretaceous/Tertiary boundary event in the ocean. In Hay, W. W. (Ed.), Studies in Paleo-oceanography. Soc. Econ. Paleontol. Mineral. Spec. Publ., 20:94-175. 